\title{
A Comparison of Pheromone and Blacklight Traps for Attracting Sugarcane Borer (Diatraea saccharalis (F.)) Adults from a Natural Population, ${ }^{1,2}$
}

\author{
Rafael Pérez Pérez and S. D. Hensley ${ }^{3}$
}

\section{INTRODUCTION}

During the past 3 decades, man has relied heavily on synthetic organic compounds for insect control. These have been highly efficient and have contributed significantly to better health, shelter and an increase in food supply in many parts of the world. Yet, in many instances, overuse has led to environmental pollution, interference with ecological food chains and significant residuc problems for man and animals. Extensive use of insecticides also has led to development of resistance in many pest species of medical and agricultural importance. Thus, there is an urgent need for control systems that rely less on insecticides and more on other methods.

More research is urgently needed on new approaches to insect control. Although it may not be possible in the foresccable future to control many of the more important insect pests affecting crops, animals or man without insecticides, their use may be reduced to minimum amounts by combining the applications of insecticides with other effective measures into integrated control programs based on sound principles of pest management.

The use of light attraction for survey purposes and/or for the control of insects dates back many years. More recently, pheromones or sex attractants have been studied for the same purpose. To date, neither approach has contributed significantly to insect control, but both methods have been utilized effectively as survey techniques for some species.

The objective undertaken in the study reported herein was to evaluate the combined offect of pheromone and light attraction for luring the adults

1 Manuseript submitted to Editorial Board March 26, 1973.

2 This work is adapted from a dissertation submitted by the senior author to the Faculty of the Graduate School at Louisiana State University and Agricultural and Mechanical College, Baton Rouge, in partial fulfillment of the requirements for the degree of Doctor in Philosophy (1971).

${ }^{3}$ Assistant Entomologist and Professor of Entomology, Agricultural Experiment Station, Mayagüez Campus, University of Puerto Rico, Río Piedras, and Louisiana State University, Baton Rouge, La., respectively. Sincere appreciation is expressed to the members of the advisory committee, Drs. L. D. Newsom, L. H. Rolston, A. M. Hammond, and W. J. Harman, Louisiana State University, for their helpful review of this manuscript. 
of the sugarcane borer, Diatraea saccharalis (F.), from natural populations.

\section{LITERATURE REVIEW}

Attraction to light and into light traps has been used for many years to survey insect populations, and in a few instances for insect control. Attempts have been made in recent years to use insect attractants or pheromones alone or in combination with light for these same purposes. A pheromone as defined by Karlson and Butenandt (15) is a substance secreted to the outside by an animal that causes a specific reaction in a receiving animal of the same species. The term pheromone is derived from the Greek "phercin" (to carry) and "horman" (to excite).

Trap lanterns were used extensively from 1860 to 1888 for survey and control of lepidopterous insects attacking cotton. Slingerland (23) reported that cotton growers for at least half a century used lanterns in traps coated with a sticky substance to lure and entrap insects. Felt (3) used trap lanterns in studies of Crambus species. Williams (26) determined the time of activity of certain nocturnal insects by using light traps. He later reported a 4-year study of light trap insect captures that included a general survey of the species trapped therein (27). Lawson et al. (18) and Gentry et al. (6) reported that populations of tobacco hornworm, MIanduca sexta (L.), and the tomato hornworm, $M$. quinquemaculata Haworth, were reduced by 88 percent in a 113-square mile area of tobacco in North Carolina when blacklight traps were operated at a density of $3 / \mathrm{sq}$. mile.

Hoffman et al. (13) found that more males of $M$. sexta were caught in blacklight traps baited with 2-30 females per trap than in blacklight traps without females. They suggested intensive experiments with femalebaited light traps in isolated areas to determine the feasibility of total population control. However, Jones and Thurston (14) concluded that a blacklight-trapping program for hornworm control on tobacco in a Kentucky area did not provide economic control.

Shorey and Gaston (22) demonstrated in laboratory experiments that males of the cabbage looper, Trichoplusia $n i$ (Hubner), would more often orient toward a light source than toward an air current carrying a weak concentration of T. ni sex attractant. Henneberry and Howland (9) found that more $T$. $n i$ males by 20 to 30 times were caught in light traps baited with pheromone than with unbaited traps. Henneberry et al. (10) found that catches of $T . n i$ males in baited light traps increased as the numbers of virgin females caged in the traps were increased, and that virgin females placed as far as 40 feet from traps increased male catch. Kishaba et al. (17) reported that electric grid traps baited with pheromone attracted more males than standard survey light traps baited with pheromone. 
Grid traps baited with pheromone plus a 15-watt lamp caught 3.1 times more males than grid traps baited only with the pheromone.

Studies of insect attraction to traps with different light intensities and wave lengths have been published by Harstock et al. (8), Frost (4), Kirkpatrick et al. (16), and Stanley and Dominick (24). Blacklight is generally more attractive to most species of insects, and 15- to 400 -wattlamps usually have been used in light trap studies.

The pheromone of Diatraea saccharalis was discovered in 1963 by Pérez and Long (21). Hensley (11) reported its effectiveness in reducing sugarcane borer damage in small field plots and Hammond and Hensley (7) developed a bioassay technique for detecting active pheromone fractions. Patrick and Hensley (20) reported on recapture of $D$. saccharalis males released at different distances from traps baited with virgin females.

\section{MATERIALS AND METHODS}

These experiments were conducted during September and October 1970 on the Westover Plantation near Rougon, Louisiana. Here, 1,600 acres of sugarcane are in production annually and insecticides are applied for control of economically damaging sugarcane borer populations in July and August. However, no insecticides are applied after August 31 and fall infestations are usually heavy, especially at the tops of the stalks where larvae cause little if any economic damage.

A 25 -acre field of sugarcane (variety CP $43-47$, first year stubble crop), located near the center of the plantation, was selected as a trapping arca. This field received two applications of azinphosmethyl applied at a rate of $0.75 \mathrm{lb}$. active ingredient/acre/application for sugarcane borer control in July and August; however, when this test was initiated on September 19, more than 25 percent of the stalks contained larvae in the leaf-sheaths of the topmost internodes. Traps were located in a 40,000-sq. yd. area in the center of this ficld.

\section{EXPERIMENTAL DESIGN}

A complete randomized-block experimental design was employed with treatments replicated 3 times. Treatments consisted of the following three types of traps: (a) Virgin females (pheromone), (b) blacklight lamps plus females entrapped from the natural population, and (c) virgin females (pheromone) and blacklight lamps plus females entrapped from the natural population in combination. The distance between traps within the trap area was 300 feet.

\section{TYPES OF TRAPS}

The basic components of all types of traps (figs. 1 and 2), i.e., stakes, trapping surface and mounts, were similar. The traps were suspended in 
the field by attaching each to a 2-inch X 2-inch X 6-feet redwood stake driven 2 feet into the soil. Trapping surfaces were constructed by sawing in half 5-gallon cylindrical plastic cans, from which the tops and bottoms had been removed. The inner surface of each trap was coated with Stikem $^{\mathbf{R} 4}$ (Michael Pelton Company, Oakland, California), an adhesive substance which served to entrap moths lured to the trap. Trap surfaces were recoated with Stikem at 3-day intervals during the trapping period.

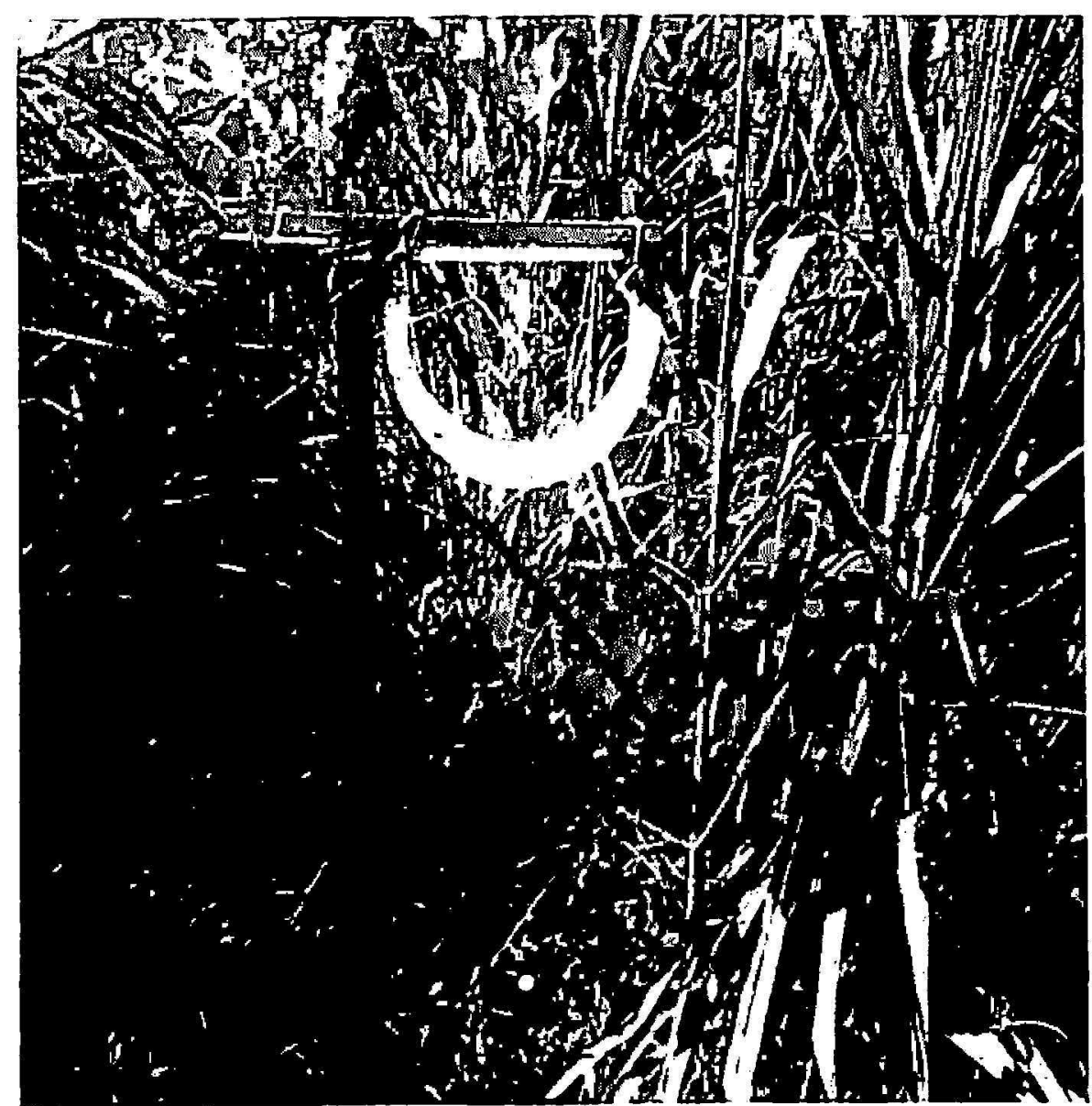

FIg. 1.-Blacklight trap used for attracting and capturing sugarcane borer moths.

For the blacklight trap (fig. 1) an F6 B5, blacklight lamp was positioned laterally 9 inches above the center of the trapping surface. This lamp was electrically wired to a transformer which in turn was wired to a 12-volt automobile battery located on the ground. An automatic switch which shut the current off during daylight hours was located within the trans-

4 Trade names are used in this publication solely for the purpose of providing specific information. Mention of a trade name does not constitute a guarantee or warranty of equipment or materials by the Agricultural Experiment Station of the University of Puerto Rico or an endorsement over other equipment or materials not mentioned. 
former; thus, the light was in operation only between sundown and daybreak.

The blacklight-pheromone trap (fig. 2) was similar in all respects to the blacklight trap (fig. 1) except that it contained five virgin female moths as bait suspended in a cage 6 inches above the trap surface. Bait moth cages were constructed from 1/2-pint ice cream cartons from which the tops and bottoms had been removed and replaced with 12-mesh copper

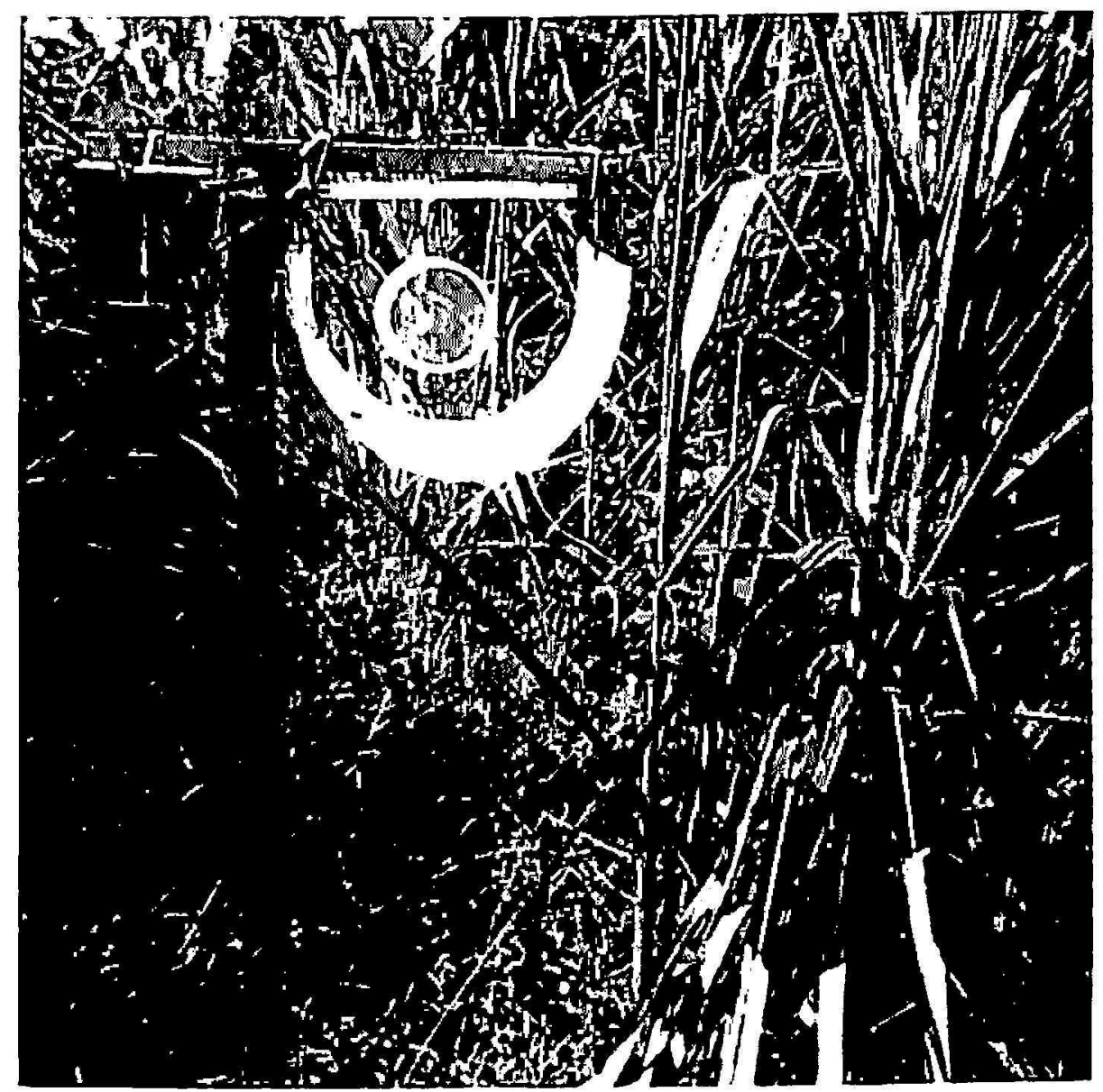

FIc. 2.-Blacklight-pheromone trap used for attracting and capturing sugarcane borer moths.

screenwire. Bait moths were replaced at 3-day intervals during the trapping period.

The pheromone trap (not shown) was similar to the blacklight-pheromone trap (fig. 2), but did not contain a blacklight lamp.

\section{LABORATORY REARING TECHNIQUES}

The sugarcane borer moths used in these experiments were obtained by rearing larvae on a Pinto bean diet (1) according to procedures described by Hensley and Hammond (12). Pupae were sexed with the aid of a binocular microscope and males and females were kept in separate but similar 
cages until emergence. Each emergence cage consisted of a 1-gallon cylindrical ice cream carton from which the top had been removed and replaced with a 64-mesh plastic screen. Pupae were confined within this cage in a 3 -inch diameter petri dish which rested on a 2 -inch layer of moist vermiculite. Emerging moths were removed daily and placed in holding cages similar to those used during emergence, except that they did not contain vermiculitc. Only 1- to 2-day-old virgin female moths were used for bait purposes in field traps. Rearing was conducted in a laboratory room at a temperature of $76^{\circ} \pm 4^{\circ} \mathrm{F}$.

\section{TRAPPING PROCEDURES}

The traps were serviced after 5 p.m. Bait cages containing virgin females less than 2 days old were placed in pheromone and pheromone-light combination traps. The blacklight lamps, transformers and batteries were checked to assure functioning. All trap surfaces were coated with Stikem. Each morning after the traps were in operation, the sugarcane borer moths caught in each trap were recorded and placed in a vial containing xylene and returned to the laboratory where they were transferred to 95 percent alcohol and held for subsequent study. Traps were operated from September 19 to October 4,1970 . The height of the sugarcane crop in the trap area during that time averaged about 7 feet.

All moths trapped were examined with the aid of a binocular microscope to determine the numbers and sex of moths attracted to different types of traps. Mating incidence of females was determined by counting the numbers of spermatophores found in the bursa copulatrix according to techniques developed by Callahan (2). Physiological age of females was determined according to methods described by Gehring and Madsen (5).

\section{RESULTS}

The number of male sugarcane borers caught in traps baited with (a) five virgin females (pheromone), (b) blacklight lamps plus females entrapped from the natural population, and (c) a combination of the two techniques is shown in table 1. A greater number of males were caught with techniques (b) and (c); i.c., those that included blacklight lamps. Differences between the number of males caught in (b) and (c) were not statistically significant but male catch in each was significantly greater when compared with treatment (a); i.e., traps baited only with virgin females.

The numbers of females caught by the three techniques are shown in table 2. No females were caught in traps baited only with virgin females (a) and 24 and 35 , respectively, were caught in traps that contained blacklight lamps. 
The reproduction status and physiological age of females attracted to blacklight traps plus the sex ratio of trapped moths are presented in table 3 . Only two of the females trapped were unmated. The bursa copulatrix of each of 32 females contained one spermatophore and 21 and four contained two and three, respectively. More than one-half of the 33 females caught were classified as belonging to the youngest age group 1, and 24 and two,

TABLE 1.-Numbers of male sugarcane borers caught in traps bailed with (a) virgin females (pheromone), (b) blacklight lamps + females attracted from the nalural population, and (c) virgin females (pheromone) + blacklight lamps + females attracted from the natural population, Westover Plantalion, Rougon, Louisiana, Seplember 19-October 4, 1970

\begin{tabular}{cc}
\hline Type of trap & Numbers from natural population \\
\hline & $M c a n^{2}$ \\
(a) & $46.6^{\mathrm{a}}$ \\
(b) & $92.0^{\mathrm{b}}$ \\
(c) & $102 . \mathrm{b}^{\mathrm{b}}$ \\
\hline
\end{tabular}

1 Means not followed by the same letter differ significantly at the 5-percent level of probability according to Duncan's multiple range test (LeClerg (19)).

TABLE 2.-Numbers of females attracted to traps baited with (a) virgin females (pheromone), (b) blacklight lamps + females altracted from the natural population, and (c) virgin females (pheromone) + blacklight lamps + females altracled from the natural population, Westover Plantation, Rougon, Louisiana, Seplember 19-Oclober 4, 1970

\begin{tabular}{cccc}
\hline Date & (a) & Treatment number (type of trap) & (b) \\
\hline $9 / 19$ & 0 & 2 & 1 \\
$9 / 20$ & 0 & 4 & 10 \\
$9 / 27$ & 0 & 12 & 16 \\
$10 / 2$ & 0 & 2 & 0 \\
$10 / 3$ & 0 & 0 & 2 \\
$10 / 4$ & 0 & 4 & 6 \\
\hline Total & 0 & 24 & 35 \\
\hline
\end{tabular}

respectively, were found to belong to age groups 2 and 3 . The sex ratio of trapped moths was found to be one female for every 9.8 males.

\section{DISCUSSION}

A comparison of the number of males attracted to different traps (table 1) shows that significantly fewer males were attracted to virgin female (pheromone) traps than to those containing blacklight lamps plus virgin 
females or blacklight lamps plus only females subsequently trapped from the natural population. However, no significant difference was found between the number of males caught in the last two types of traps mentioned. This phenomenon only serves to emphasize the difficulty of attempting to separate the effect of pheromone from that of light, as a "light" trap also becomes a pheromone trap once female moths are attracted to it and retained alive.

The ratio of males to females caught in blacklight traps was 10 to one, respectively, in these experiments (table 3). Steward et al. (25) also reported a low ratio of about one female to six males in blacklight trapping experiments with the tobacco hornworm, $M$. sexta. Pérez and Long (21) found a ratio of 5.4 females to 4.6 males in catches of $D$. saccharalis from traps located on the Hill Farm at Louisiana State University, Baton

TABLE 3.-Reproductive stalus and physiological age of female sugarcane borers and sex ratio of calch from six blacklight traps, Westover Plantation, Rougon, Louisiana, Sept.19-Oct. 4, 19711

\begin{tabular}{|c|c|c|c|c|c|c|c|c|}
\hline \multirow{2}{*}{$\begin{array}{l}\text { Total } \\
\text { number } \\
\text { trapped }\end{array}$} & \multicolumn{4}{|c|}{$\begin{array}{l}\text { Number with } 0,1,2 \text { or } 3 \text { spermatophores } \\
\text { in the bursa copulatrix²- }\end{array}$} & \multicolumn{3}{|c|}{$\begin{array}{l}\text { Number in physiological } \\
\text { age groups } 1,2 \text { or } 3^{2}\end{array}$} & \multirow{2}{*}{$\begin{array}{l}\text { Sex ratio of } \\
\text { trapped moths } \\
\text { (females: males) }\end{array}$} \\
\hline & (0) & (1) & (2) & (3) & (1) & (2) & (3) & \\
\hline 59 & 2 & 32 & 21 & 4 & 33 & 24 & 2 & $1: 9.8$ \\
\hline
\end{tabular}

1 Figures are total numbers trapped in six traps.

2 Determined by techniques developed by Callahan (2).

${ }^{3}$ Age groups are categorized from youngest (1) to oldest (3) according to the age classification developed by Gehring and Madsen (5).

Rouge. These observations only serve to emphasize that sex ratios of Lepidoptera caught in light traps vary greatly depending on the type of lamp and design of trap and that light traps probably are of little value for studying the sex ratios of natural insect populations.

Of $59 \mathrm{D}$. saccharalis females caught in light traps during this investigation, 32 had mated once; 22 twice; and four, three times, based on the number of spermatophores found in the bursa copulatrix of each female trapped (table 3). Thus, light traps may not reflect the true reproductive status of natural populations, as $D$. saccharalis moths shaken from sugarcane plants in the field indicate a much lower incidence of multiple mating.

\section{SUMMARY}

Comparison of traps baited with: (a) virgin females (pheromone), (b) blacklight lamps plus females entrapped from the natural population, and (c) virgin females (pheromone) and blacklight lamps plus females entrapped from the natural population, indicated no significant difference between 
the traps containing blacklight lamps plus females entrapped from the natural population and those traps containing blacklight lamps plus virgin females in catches of Diatraea saccharalis (F.) males from the natural population. Both types of traps, however, caught significantly more males than traps baited only with virgin females. Most of the female moths trapped were less than 2 days old and most had mated only once. The sex ratio of moths trapped was 1 female: 9.8 males.

\section{RESUMEN}

Se comparó el grado de atracción de machos adultos del barrenador de la caña de azúcar, Dialraea saccharalis (F.), de tres tipos de trampas, a saber, (a) unas que solo contenian hembras vírgenes (feromona), (b) lámparas de luz negra solamente y (c) lámparas de luz negra con hembras vírgenes (feromona). Los resultados indicaron que no existe diferencia significativa alguna $(p=0.05)$ entre las trampas que contienen lámparas de luz negra solamente y las que contienen lámparas de luz negra más hembras vírgenes. Sin embargo, ambos tipos de trampas atrajeron significativamente $(p=0.05)$ más machos adultos de la población natural que la que solo contenía hembras virgenes como señuelo. Se determinó que la mayoría de las hembras adultas atraidas de la población natural hacia las trampas que contenían luz negra tenían 2 días o menos de edad y que de éstas, la mayoría había copulado solamente una vez. Se encontró también que por cada hembra atraída a las trampas de donde emanaba la luz negra había un promedio de 9.8 machos igualmente atraídos a las mismas.

\section{LITERATURE CITED}

1. Burton, R. L., Mass rearing of the corn earworm in the laboratory, ERD Bull. 33-134: 3-8, ARS, USDA, 1967.

2. Calluhan, P.S., Behavior of the imago of the corn earworm, Heliothis zea (Boddie) with special reference to emergence and reproduction, Ann. Entomol. Soc. Amer. 51: 271-83, 1958.

3. Felt, E. P., On certain grass eating insects, Cornell Univ. Agr. Exp. Sta. Bull. 64: 45-102, 1894.

4. Frost, S. W., A trap to test the response of insects to various light intensities, J. Econ. Entomol. 63: 1,344-46, 1970.

5. Gehring, R. D., and Madsen, H. F., Some aspects of the mating and oviposition behavior of the codling moth, Carpocapsa pomonella, J. Econ. Entomol. 56: $140-43,1963$.

6. Gentry, C. E., Lawson, F. R., Knott, C. M., Stanley, J. M., and Lam, J. J., Control of hornworms by trapping with blacklight and stalk cutring in North Carolina, J. Econ. Entomol. 60: 1,437-42, 1967.

7. Hammond, A. M., and Hensley, S. D., Bioassay of the sex attractant in the sugarcane borer, Ann. Entomol. Soc. Amer. 63: 64-66, 1968.

8. Harstock, J. G., Jeay, H. D., and Barret, J. R., Practical application of insect attraction in the use of light traps, Bull. Entomol. Soc. Amer. 12: 375-77, 1966.

9. Henneberry, T. G., and Howland, A. F., 1966, Response of male cabbage looper to blacklight with and without the presence of the female sex pheromone, J. Econ. Entomol. 59: 623-26, 1966.

10. -, -, and Wolf, W. W., Combination of blacklights and virgin females as attractants to cabbage looper moths, J. Econ. Entomol. 60: 152-56, 1970. 
11. Hensley, S. D., Research on the sugarcane borer sex attractant. (A progress report), Sugar J. 29 (12): 40-43, 1968.

12. - , and Hammond, A. M., Laboratory techniques for rearing the sugarcane borer on artificial diet, J. Econ. Entomol. 61: 1,742-43, 1968.

13. Hoffman, J. D., Lawson, F. R., and Peace, B., Attraction of blacklight traps baited with virgin females of the tobacco hornworm moth, J. Econ. Entomol. 63: 1,187-94, 1970.

14. Jones, G. A., and Thurston, R., Effect of an area program using blacklight traps to control populations of the tobacco hornworm in Kentucky, J. Econ. Entomol. 63: 1,187-94, 1970.

15. Karlson, P., and Butenandt, A., Pheromones (ectohormones) in insects, Ann. Rev. Entomol. 4: 39-58, 1959.

16. Kirkpatrick, R. R., Yancey, D. L., and Marzke, F. O., Effectiveness of green and ultraviolet light in attracting stored products insects to traps, J. Econ. Entomol. 63: 871-73, 1970.

17. Kishaba, A. N., Wolf, W. W., Toba, H. H., Howland, A. F., and Gibson, T., Light and synthetic pheromone as attractants for male cabbage loopers, J. Econ. Entomol. 63: 1,+17-20, 1970.

18. Lawson, F. R., Gentry, C. R., and Stanley, J. N., Effect of light traps on hornworm population in large areas, ARS, USDA 33-91, 18 pp., 1963.

19. LeClerg, E. L., Mean separation by the functional analysis of variance and multiple comparisons, Bull. 20-3: 33 pp., ARS, USDA, 1957.

20. Patrick, J. C., and Hensley, S. D., Recapture of males released at different distances from a trap baited with virgin female sugarcane borers, J. Econ. Entomol. 63: 1,341-42, 1970.

21. Pérez, R., and Long, W. H., Sex attractant and mating behavior of the sugarcane borer, J. Econ. Entomol. 57 : 688-90, 1964.

22. Shorey, H. H., and Gaston, L. K., Sex pheromones of noctuid moths, VIII. Orientation to light by pheromone stimulated males of T. ni., Ann. Entomol. Soc. Amer. 58: 833-36, 1965.

23. Slingerland, M. V., Trap lanterns or "Moth Catchers", Cornell Univ. Agr. Exp. Sta. Bull. 212: 197-241, 1902.

24. Stanley, J. M., and Dominick, C. B., Funnel size and lamp wattage influence on light trap performance, J. Econ. Entomol. 63: 1,423-26, 1970.

25. Steward, D. A., Lam, J. J., and Hoffman, J. D., Activity of tobacco hornworm and corn earworm moths as determined by traps equipped with blacklight lamps, J. Econ. Entomol. 60: 1,520-22, 1967.

26. Williams, C. B., The time of activity of certain nocturnal insects, chiefly Lepidoptera, as indicated by a light trap, Trans. Roy. Entomol. Soc. Lond. 83: 523$55,1935$.

27. - An analysis of four years capture of insects in a light trap, Trans. Roy. Entomol. Soc. Lond. 89: 73-131, 1939. 